\title{
Tetrahedron
}

\section{Photochromic reaction behavior and thermal stability of thiophene-S,S-dioxidized diarylethenes having a benzofuryl group}

\author{
Koki Tanaka, Daichi Kitagawa, Seiya Kobatake* \\ Department of Applied Chemistry, Graduate School of Engineering, Osaka City University, \\ 3-3-138 Sugimoto, Sumiyoshi-ku, Osaka 558-8585, Japan \\ *Corresponding author.Tel. \& fax: +81-6-6605-2797; e-mail: kobatake@a-chem.eng.osaka-cu.ac.jp
}

\section{ARTICLE INFO}

Article history:

Received

Received in revised form

Accepted

Available online

Keywords:

Photochromism

Diarylethene

Thermal reaction

DFT calculation

\section{ABSTRACT}

Diarylethenes having a benzofuryl group and their thiophene- $S, S$-dioxidized diarylethenes were synthesized and their optical properties and thermal stability were investigated. Upon oxidation of the thiophene ring, the optical properties such as absorption maxima, photocycloreversion quantum yields, and conversion from the open-ring isomer to the closed-ring isomer have changed. On the other hand, the thermal stability of the closed-ring isomers of the $S, S$-dioxidized diarylethenes is significantly higher than those of thiophene- $S, S$-dioxidized diarylethenes having a phenylthienyl group instead of a benzofuryl group. The high thermal stability of the closedring isomer was quantitatively discussed based on ground state energies obtained by quantum chemical calculations.

2009 Elsevier Ltd. All rights reserved.

\section{Introduction}

A lot of photochromic compounds have been so far synthesized and investigated because they have a potential for use in application such as ophthalmic lenses, ${ }^{1}$ optical memories, ${ }^{2}$ photooptical switches, ${ }^{3}$ displays, ${ }^{4}$ nonlinear optics, ${ }^{5}$ and photoresponsive actuators. ${ }^{6}$ Especially, diarylethene derivatives are one of the representative photochromic compounds and can modulate physicochemical properties such as conductivity, dielectric constant, refractive index, and fluorescence according to photochromic reactions. ${ }^{7,8}$ Furthermore, in recent studies, thiophene oxidized diarylethenes have attracted much attention because they have different properties from non-oxidized diarylethenes. For example, Kim and Ahn and coworkers have reported that while non-oxidized diarylethenes show no fluorescence at room temperature, diarylethenes having dioxidized benzothienyl groups as both aryl groups showed a strong fluorescent property in the closed-ring isomer. ${ }^{9-11}$ Irie and coworkers have reported that the oxidized diarylethenes introducing ethyl groups at the reactive carbons showed much larger fluorescence quantum yields $\left(\Phi_{\mathrm{f}}=0.6-0.9\right)$ in the closedring isomer. ${ }^{12,13}$ Kawai and coworkers have also reported that oxidized terarylenes showed relatively high fluorescence properties $\left(\Phi_{\mathrm{f}}=0.34-0.36\right) .{ }^{14}$ These turn-on mode fluorescence switching systems are expected for application to optical recording media and biological systems.

On the other hand, we have reported the thermal irreversible reaction in the closed-ring isomer of diarylethenes having a dioxidized phenylthienyl group. ${ }^{15,16}$ The closed-ring isomers of
thiophene-S,S-dioxidized diarylethenes with secondary alkyl substituents at the reactive positions were found to undergo thermal bleaching reactions to produce byproducts. The rate of the thermal bleaching reactions can be controlled by the bulkiness of the substituent at the reactive positions and the introduction of methyl groups at the 4-position of the thiophene rings. Such materials can be used in application such as lightstarting irreversible thermosensors. Thus, the investigation of novel oxidized diarylethenes is of great interest for making new functional photochromic materials.

Here, we have synthesized diarylethenes having a benzofuryl group (1a-3a) and their thiophene- $S, S$-dioxidized diarylethenes $(\mathbf{1 b}-\mathbf{3 b})$ as shown in Scheme 1. The photochromic reaction behavior and thermal stability of the closed-ring isomers are discussed in this paper.

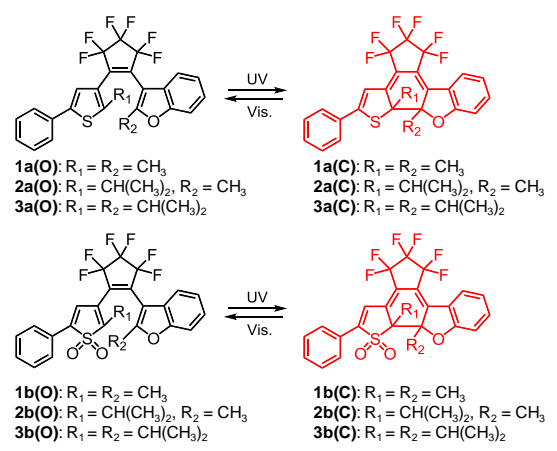

Scheme 1. Photochromic diarylethenes used in this work. 


\section{Results and Discussion}

\subsection{Photochromic reaction behavior}

Diarylethenes 1a-3a and thiophene-S,S-dioxidized

2 diarylethenes $\mathbf{1 b}-\mathbf{3 b}$ showed reversible photochromic reactions

3 upon alternating irradiation with ultraviolet (UV) and visible

4 light. In their diarylethenes, the photocyclization and

5 photocycloreversion reactions can be repeated for several cycles.

6 Fig. 1 shows the absorption spectral changes of diarylethenes

$7 \mathbf{1 a}-\mathbf{3 a}$ and thiophene- $S, S$-dioxidized diarylethenes $\mathbf{1 b}-\mathbf{3 b}$ in $n$ -

8 hexane. The open-ring isomers $\mathbf{1 a}(\mathbf{O})-\mathbf{3 a}(\mathbf{O})$ have absorption

9 maxima around $250 \mathrm{~nm}$. Upon irradiation with $313 \mathrm{~nm}$ light, the In order to compare the photoreactivity before and after the
oxidation of the thiophene ring, the molar absorption coefficient $(\varepsilon)$, the photocyclization quantum yield $\left(\Phi_{0 \rightarrow c}\right)$, the photocycloreversion quantum yield $\left(\Phi_{\mathrm{c} \rightarrow 0}\right)$, and the conversion from the open-ring isomer to the closed-ring isomer were determined as shown in Table 1. By the oxidation of the thiophene ring, the absorption maxima of the closed-ring isomers $\mathbf{1 b}(\mathbf{C})-\mathbf{3 b}(\mathbf{C})$ were blue-shifted in comparison with those of $\mathbf{1 a}(\mathbf{C})-\mathbf{3 a}(\mathbf{C})$. Although the photocyclization quantum yields scarcely changed, the photocycloreversion quantum yields significantly decreased by a factor of $10-10^{2}$ upon the oxidation. Moreover, the conversion from the open-ring isomer to the closed-ring isomer increased up to $96-100 \%$ upon the oxidation. These results are similar to those of the thiophene-S,S-dioxidized diarylethenes having a phenylthienyl group. ${ }^{9}$

Table 1

Optical properties of diarylethenes in $n$-hexane

\begin{tabular}{|c|c|c|c|c|c|c|c|}
\hline & \multicolumn{2}{|c|}{ open-ring isomer } & \multicolumn{2}{|c|}{ closed-ring isomer } & \multirow{2}{*}{$\Phi_{0 \rightarrow c}$} & \multirow{2}{*}{$\Phi_{\mathrm{c} \rightarrow \mathrm{o}}$} & \multirow{2}{*}{$\begin{array}{c}\text { Conv.l } \\
\%\end{array}$} \\
\hline & $\lambda_{\max } / \mathrm{nm}$ & $\varepsilon / \mathrm{M}^{-1} \mathrm{~cm}^{-1}$ & $\lambda_{\max } / \mathrm{nm}$ & $\varepsilon / \mathrm{M}^{-1} \mathrm{~cm}^{-1}$ & & & \\
\hline $1 \mathrm{a}$ & 257 & 29400 & 525 & 18100 & 0.39 & 0.088 & 89 \\
\hline $2 \mathbf{a}$ & 256 & 23400 & 542 & 14000 & 0.52 & 0.20 & 84 \\
\hline $3 \mathbf{a}$ & 255 & 27000 & 552 & 14400 & 0.51 & 0.14 & 84 \\
\hline $1 \mathrm{~b}$ & 341 & 7200 & 470 & 19000 & 0.39 & 0.0066 & 96 \\
\hline $2 b$ & 337 & 8400 & 479 & 20700 & 0.39 & 0.0028 & 98 \\
\hline $3 b$ & 339 & 8500 & 491 & 20300 & 0.30 & 0.0024 & $\sim 100$ \\
\hline
\end{tabular}

\subsection{Thermal stability of the closed-ring isomer}

The closed-ring isomers of diarylethenes having bulky substituents at the reactive carbons, such as isopropyl or isobutyl groups, show thermal cycloreversion reaction to the open-ring isomers. ${ }^{17-23}$ On the other hand, the closed-ring isomers of the thiophene- $S, S$-dioxidized diarylethenes having secondary alkyl groups at the reactive positions undergo a thermally irreversible reaction to produce byproducts. Byproducts are produced by elimination of the sulfonyl group and rearrangement of the secondary alkyl group from the closed-ring isomer upon heating as shown in Scheme 2. ${ }^{15,16}$ The photogenerated closed-ring isomer $(\mathbf{4 b}(\mathbf{C}))$ of the oxidized diarylethene having isopropyl groups at the reactive positions $(4 \mathbf{b}(\mathbf{O}))$ formed three byproducts upon heating.

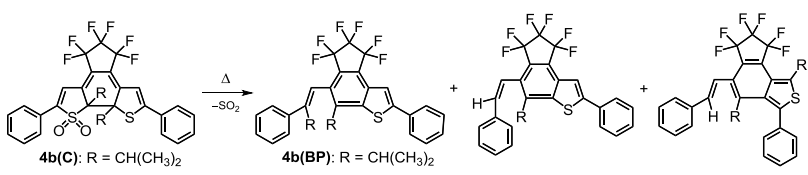

Scheme 2. Thermal byproducts formation of thiophene-S,S-dioxidized diarylethene closed-ring isomer $\mathbf{4 b}(\mathbf{C})$.

Here, we investigated the thermal reaction behavior of the closed-ring isomers $\mathbf{1 a}(\mathbf{C})-\mathbf{3 a}(\mathbf{C})$ and $\mathbf{1 b}(\mathbf{C})-\mathbf{3 b}(\mathbf{C})$. Fig. 2 shows the absorbance changes of the colored solutions of $\mathbf{1 a}(\mathbf{C})-\mathbf{3 a}(\mathbf{C})$ and $\mathbf{1 b}(\mathbf{C})-\mathbf{3 b}(\mathbf{C})$ in toluene at $110{ }^{\circ} \mathrm{C}$. Before the oxidation, $1 \mathbf{a}(\mathbf{C})$ and $\mathbf{2 a}(\mathbf{C})$ did not show any decoloration even after $10 \mathrm{~h}$. On the other hand, the absorbance of $\mathbf{3 a}(\mathbf{C})$ slightly decreased. This is due to the introduction of bulky isopropyl substituents at both reactive carbons. After the oxidation of a thiophene ring, $\mathbf{1 b}(\mathbf{C})-\mathbf{3 b}(\mathbf{C})$ caused less thermal decoloration reaction even after $10 \mathrm{~h}$ at $110{ }^{\circ} \mathrm{C}$, regardless of the introduction of bulky isopropyl substituents at the reactive carbons. These results are different from those of the thiophene-S,S-dioxidized diarylethenes having the phenylthienyl group. This is ascribed to the introduction of a benzofuryl group instead of a phenylthienyl group. 

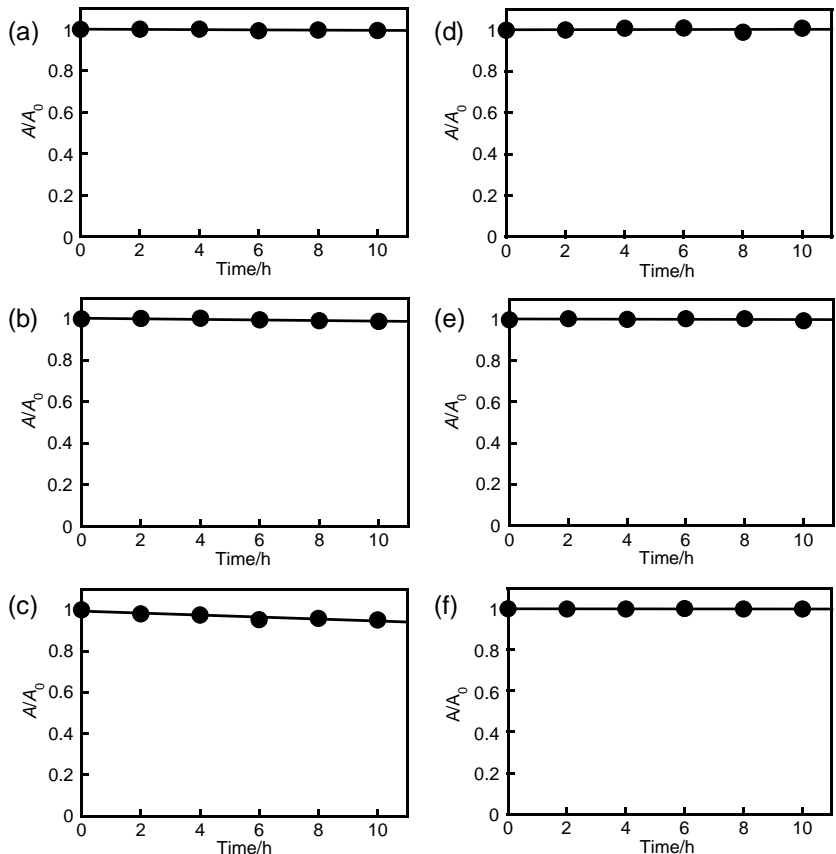

Fig. 2. Absorbance change of $\mathbf{1 a}(\mathbf{C})(\mathrm{a}), \mathbf{2 a}(\mathbf{C})(\mathrm{b}), \mathbf{3 a}(\mathbf{C})(\mathrm{c}), \mathbf{1 b}(\mathbf{C})(\mathrm{d})$, $\mathbf{2 b}(\mathbf{C})(\mathrm{e})$, and $\mathbf{3 b}(\mathbf{C})(\mathrm{f})$ in toluene at $110^{\circ} \mathrm{C}$.

In order to quantitatively discuss the thermal stability of the closed-ring isomer of diarylethenes, the energy difference $(\Delta H)$ between the open- and closed-ring isomers in the ground states and the energy difference $\left(\Delta H^{\prime}\right)$ between the closed-ring isomer and the total energy of byproduct and $\mathrm{SO}_{2}$ were calculated by density functional theory (DFT) at the B3LYP/6-31G(d) level. The energy of $\mathrm{SO}_{2}$ was calculated to be $-1440317.2 \mathrm{~kJ} \mathrm{~mol}^{-1}$. For comparison, the $\Delta H$ and $\Delta H^{\prime}$ values of the thiophene-S,Sdioxidized diarylethene having a phenylthienyl group (4b) were also calculated. Table 2 shows ground state energies of the openring isomer $(\mathbf{O})$, the closed-ring isomer $(\mathbf{C})$, the byproduct $(\mathbf{B P})$, and their energy differences $\left(\Delta H\right.$ and $\left.\Delta H^{\prime}\right)$. In our previous work, it was clarified that diarylethenes having $\Delta H$ value over about 60 $\mathrm{kJ} \mathrm{mol}^{-1}$ exhibit the thermal cycloreversion reaction at $100{ }^{\circ} \mathrm{C}^{16}$ Before the oxidation, the $\Delta H$ values of $\mathbf{1 a - 3 a}$ are $37.90,61.01$, and $88.95 \mathrm{~kJ} \mathrm{~mol}^{-1}$, respectively. These values suggest that only the closed-ring isomer $\mathbf{3 a}(\mathbf{C})$ shows the thermal cycloreversion reaction at $100{ }^{\circ} \mathrm{C}$, which is consistent with the experimental results. After the oxidation, the $\Delta H$ values of $\mathbf{1} \mathbf{b}-\mathbf{3 b}$ are much smaller than $60 \mathrm{~kJ} \mathrm{~mol}^{-1}$, which means that the closed-ring isomers of the thiophene-S,S-dioxidized diarylethenes $\mathbf{1 b}(\mathbf{C})-\mathbf{3 b}(\mathbf{C})$ cannot undergo thermal cycloreversion reactions at $100{ }^{\circ} \mathrm{C}$. This is also consistent with the experimental results.

Next, we discuss the $\Delta H^{\prime}$ values for the thiophene- $S, S$ dioxidized diarylethenes. The $\Delta H^{\prime}$ values of $\mathbf{1 b}, \mathbf{2} \mathbf{b}$, and $\mathbf{3 b}$ were estimated to be $148.22,179.51$, and $198.94 \mathrm{~kJ} \mathrm{~mol}^{-1}$, respectively, by the DFT calculation. These values are smaller than $214.56 \mathrm{~kJ}$ $\mathrm{mol}^{-1}$ for $4 \mathrm{~b}$ that undergoes the thermal bleaching reaction to produce byproducts. ${ }^{15,16}$ The relationships between the $\Delta H^{\prime}$ values and the logarithm of the rate constant $(k)$ at $100{ }^{\circ} \mathrm{C}$ and activation energy $\left(E_{\mathrm{a}}\right)$ for the thermal byproduct formation of the thiophene- $S, S$-dioxidized diarylethenes have been reported previously as shown in Fig. 3. ${ }^{16}$ The relationships are expressed as follows:

$$
\begin{gathered}
\log \left(k / \mathrm{s}^{-1}\right)=0.114 \times\left(\Delta H^{\prime} / \mathrm{kJ} \mathrm{mol}^{-1}\right)-27.8 \\
\left(E_{\mathrm{a}} / \mathrm{kJ} \mathrm{mol}^{-1}\right)=-0.968 \times\left(\Delta H^{\prime} / \mathrm{kJ} \mathrm{mol}^{-1}\right)+329
\end{gathered}
$$

Table 2

Energy gap $(\Delta H)$ calculated between the open- and closed-ring isomers and energy gap $\left(\Delta H^{\prime}\right)$ calculated between the dioxidized closed-ring isomer and the byproduct.

\begin{tabular}{ccc}
\hline & $\Delta H / \mathrm{kJ} \mathrm{mol}^{-1}$ & $\Delta H^{\prime} / \mathrm{kJ} \mathrm{mol}^{-1}$ \\
\hline $\mathbf{1 a}$ & 37.90 & \\
$\mathbf{2 a}$ & 61.01 & \\
$\mathbf{3 a}$ & 88.95 & \\
\hline $\mathbf{1 b}$ & -25.89 & 148.22 \\
$\mathbf{2 b}$ & 6.48 & 179.51 \\
$\mathbf{3 b}$ & 38.82 & 198.94 \\
$\mathbf{4 b}$ & 57.31 & 214.56 \\
\hline
\end{tabular}
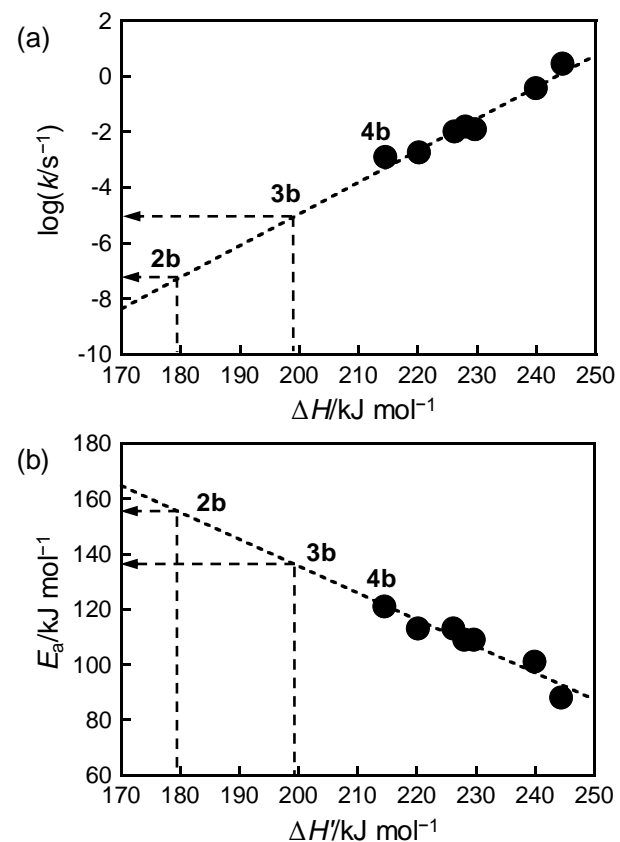

Fig. 3. Relationship between $\Delta H^{\prime}$ and the logarithm of $k$ at $100{ }^{\circ} \mathrm{C}$ (a) and the activation energy (b) for the thermal byproduct formation of the oxidized diarylethenes.

From these relationships with the $\Delta H^{\prime}$ values, the $k$ values at $100{ }^{\circ} \mathrm{C}$ and the $E_{\text {a }}$ values of $\mathbf{2 b}$ and $\mathbf{3 b}$ were calculated to be $k=$ $1.3 \times 10^{-11} \mathrm{~s}^{-1}$ and $E_{\mathrm{a}}=186 \mathrm{~kJ} \mathrm{~mol}^{-1}$ for $\mathbf{1 b}, k=4.6 \times 10^{-8} \mathrm{~s}^{-1}$ and $E_{\mathrm{a}}=155 \mathrm{~kJ} \mathrm{~mol}^{-1}$ for $\mathbf{2 b}$, and $k=7.6 \times 10^{-6} \mathrm{~s}^{-1}$ and $E_{\mathrm{a}}=136 \mathrm{~kJ}$ $\mathrm{mol}^{-1}$ for $\mathbf{3 b}$ as shown in Table 3. Compared with the values for 4b $\left(k=1.2 \times 10^{-3} \mathrm{~s}^{-1}\right.$ and $\left.E_{\mathrm{a}}=121 \mathrm{~kJ} \mathrm{~mol}^{-1}\right)$, the $k$ value decreased by a factor of $10^{2}-10^{8}$ and the $E_{\mathrm{a}}$ value became significantly large. This is due to the decrease in aromatic stabilization energy by the introduction of the benzofuryl group instead of the phenylthienyl group, which results in the destabilization of the open-ring isomer and the byproduct in the ground state as shown in Fig. 4. As a result, the closed-ring isomer $\mathbf{1 b}(\mathbf{C})-\mathbf{3 b}(\mathbf{C})$ could not cause the thermal bleaching reaction even at $110{ }^{\circ} \mathrm{C}$. Thus, the thermal reaction behavior of the closed-ring isomer could be explained by the quantum chemical calculations. 
Table 3

The rate constant and activation energy of the thermal byproduct formation for $\mathbf{2 b}(\mathbf{C}), \mathbf{3 b}(\mathbf{C})$, and $\mathbf{4 b}$ at $100^{\circ} \mathrm{C}$.

\begin{tabular}{|c|c|c|c|}
\hline & & $\mathrm{k} / \mathrm{s}^{-1}$ at $100^{\circ} \mathrm{C}$ & $E_{\mathrm{a}} / \mathrm{kJ} \mathrm{mol}^{-1}$ \\
\hline & $1 b(C)$ & $1.3 \times 10^{-11 \text { a) }}$ & $186^{\text {a) }}$ \\
\hline & $2 b(C)$ & $4.6 \times 10^{-8}$ a) & $155^{\text {a) }}$ \\
\hline & $3 b(C)$ & $7.6 \times 10^{-6 a)}$ & $136^{\text {a) }}$ \\
\hline & $4 b(C)$ & $\left.1.2 \times 10^{-3 b}\right)$ & $121^{b)}$ \\
\hline
\end{tabular}

a) Calculated values. b) Experimental values. out using a constant temperature chamber ESPEC ST-110. The sample in an optical quartz cell was degassed and sealed off under vacuum. High-performance liquid chromatography (HPLC) was carried out using a HITACHI HPLC system equipped with a Kanto Chemical Mightysil Si 60 column. The difference in energy in the ground states was calculated using Spartan'14 computational software. The molecular structures were fully optimized at the B3LYP/6-31G(d) level of theory, and vibrational frequencies for all optimized species were computed at the same level to confirm each stationary point to be a minimum.

\subsection{Materials.}

Diarylethenes 1a-3a and thiophene-S,S-dioxidized diarylethenes $\mathbf{1 b}-\mathbf{3 b}$ were synthesized as shown in Scheme 3. Compounds 5-12 were prepared by similar methods according to the procedures described in the literature. ${ }^{24-26}$

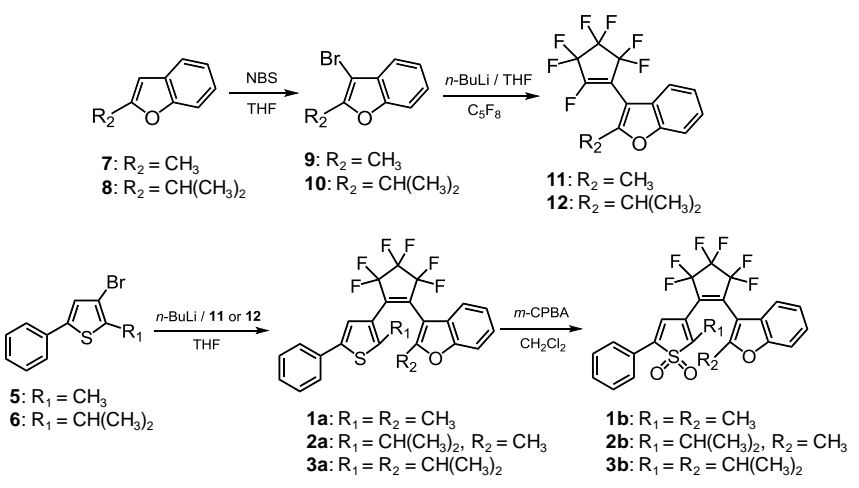

Scheme 3. Synthetic routes of diarylethenes and thiophene-S,S-dioxidized diarylethenes.

\subsubsection{1-(2-Methyl-3-benzofuryl)-2-(2-methyl-5- phenyl-3-thienyl)perfluorocyclopentene (1a)}

$n$-BuLi (1.6 M solution in $n$-hexane) $(0.32 \mathrm{~mL}, 0.51 \mathrm{mmol})$ was slowly added to a stirred dry THF solution $(5.0 \mathrm{~mL})$ containing compound 5 (120 mg, $0.46 \mathrm{mmol})$ at $-78{ }^{\circ} \mathrm{C}$ under argon atmosphere. After the mixture has been stirred for $2 \mathrm{~h}$, compound $11(150 \mathrm{mg}, 0.46 \mathrm{mmol})$ in dry THF was added to the mixture. The reaction was further stirred at $-78{ }^{\circ} \mathrm{C}$ for $2 \mathrm{~h}$, and the reaction was allowed to slowly warm up to room temperature. The reaction was quenched by the addition of water. The product was extracted with diethyl ether. The organic layer was dried over $\mathrm{MgSO}_{4}$, filtered, and concentrated. The crude product was purified by column chromatography on silica gel ( $n$-hexane/ethyl acetate $=9: 1)$ and by HPLC $(n$-hexane/ethyl acetate $=98: 2)$ to give $68 \mathrm{mg}$ of $\mathbf{1 a}$ in $47 \%$ yield as a colorless crystal. $\mathrm{mp} 155-$ $156{ }^{\circ} \mathrm{C} .{ }^{1} \mathrm{H}$ NMR $\left(300 \mathrm{MHz}, \mathrm{CDCl}_{3}, \mathrm{TMS}\right) \delta=1.88\left(\mathrm{~s}, 3 \mathrm{H}, \mathrm{CH}_{3}\right)$, $2.13\left(\mathrm{~s}, 3 \mathrm{H}, \mathrm{CH}_{3}\right), 7.1-7.6\left(\mathrm{~m}, 10 \mathrm{H}\right.$, Aromatic H). ${ }^{13} \mathrm{C}$ NMR $(75$ $\left.\mathrm{MHz}, \mathrm{CDCl}_{3}\right) \delta=13.5,14.9,105.7,111.2,120.2,122.5,123.8$, $124.7,125.8,126.4,128.1,129.2,133.4,141.5,142.5,154.3$, 156.3. IR $\left(v, \mathrm{KBr}, \mathrm{cm}^{-1}\right): 432,474,544,575,694,756,798,841$, 891, 926, 987, 1065, 1126, 1192, 1273, 1338, 1435, 1458, 1597, 1635, 2854, 2920, 2958, 3024, 3070. HRMS (MALDI) $\mathrm{m} / \mathrm{z}=$ $478.0819\left(\mathrm{M}^{+}\right)$. Calcd for $\mathrm{C}_{25} \mathrm{H}_{16} \mathrm{~F}_{6} \mathrm{OS}=478.0821$.

\subsubsection{1-(2-Methyl-3-benzofuryl)-2-(2-isopropyl-5- phenyl-3-thienyl)perfluorocyclopentene (2a)}

$n$-BuLi (1.6 M solution in $n$-hexane) $(0.73 \mathrm{~mL}, 1.2 \mathrm{mmol})$ was slowly added to a stirred dry THF solution $(5.0 \mathrm{~mL})$ containing compound 6 (300 mg, $1.1 \mathrm{mmol})$ at $-78{ }^{\circ} \mathrm{C}$ under argon atmosphere. After the mixture has been stirred for $2 \mathrm{~h}$, compound 11 (350 mg, $1.1 \mathrm{mmol}$ ) in dry THF was added to the mixture. The reaction was further stirred at $-78{ }^{\circ} \mathrm{C}$ for $2 \mathrm{~h}$, and the reaction was allowed to slowly warm up to room temperature. 
The reaction was quenched by the addition of water. The product was extracted with diethyl ether. The organic layer was dried over $\mathrm{MgSO}_{4}$, filtered, and concentrated. The crude product was 1 purified by column chromatography on silica gel ( $n$-hexane/ethyl

Chloroperbenzoic acid ( $m$ CPBA) $(63 \mathrm{mg}, 0.37 \mathrm{mmol})$ was added to a stirred dichloromethane solution $(3.0 \mathrm{~mL})$ containing $1 \mathrm{a}(50 \mathrm{mg}, 0.11 \mathrm{mmol})$. The reaction mixture was stirred overnight in the dark at room temperature. The reaction mixture was extracted with dichloromethane. The organic phase was dried over $\mathrm{MgSO}_{4}$, filtered, and evaporated. The crude product was purified by column chromatography on silica gel (nhexane/ethyl acetate $=9: 1)$ and by HPLC ( $n$-hexane/ethyl acetate $=95: 5$ ) to give $34 \mathrm{mg}$ of $\mathbf{1 b}$ in $64 \%$ yield as a pale yellow crystal. mp 99-100 ${ }^{\circ} \mathrm{C}$. ${ }^{1} \mathrm{H}$ NMR (300 MHz, $\left.\mathrm{CDCl}_{3}, \mathrm{TMS}\right) \delta=1.83(\mathrm{~s}$, $\left.3 \mathrm{H}, \mathrm{CH}_{3}\right), 2.30\left(\mathrm{~s}, 3 \mathrm{H}, \mathrm{CH}_{3}\right), 6.80(\mathrm{~s}, 1 \mathrm{H}$, Aromatic $\mathrm{H}), 7.2-7.7$ $\left(\mathrm{m}, 9 \mathrm{H}\right.$, Aromatic H). ${ }^{13} \mathrm{C} \mathrm{NMR}\left(75 \mathrm{MHz}, \mathrm{CDCl}_{3}\right) \delta=9.3,13.9$, $105.3,111.6,119.7,120.2,124.4,125.6,126.4,126.7,129.5$, 131.0, 141.9, 154.4. IR $\left(v, \mathrm{KBr}, \mathrm{cm}^{-1}\right): 424,463,540,687,748$, $795,833,876,930,991,1057,1084,1138,1192,1277,1311$, 1342, 1431, 1585, 1624, 2854, 2920, 2989, 3032, 3070, 3093. HRMS (MALDI) $m / z=510.0718\left(\mathrm{M}^{+}\right)$. Calcd for $\mathrm{C}_{25} \mathrm{H}_{16} \mathrm{~F}_{6} \mathrm{O}_{3} \mathrm{~S}=$ 510.0719 .
4.2.5. 1-(2-Methyl-3-benzofuryl)-2-(2-isopropyl-5phenyl-1,1-dioxide-3-thienyl)perfluorocyclopentene $(\mathbf{2 b})$

$m$ CPBA (68 mg, $0.40 \mathrm{mmol})$ was added to a stirred dichloromethane solution $(2.0 \mathrm{~mL})$ containing $\mathbf{2 a}(50 \mathrm{mg}, 0.10$ mmol). The reaction mixture was stirred overnight in the dark at room temperature. The reaction mixture was extracted with dichloromethane. The organic phase was dried over $\mathrm{MgSO}_{4}$, filtered, and evaporated. The crude product was purified by column chromatography on silica gel $(n$-hexane/ethyl acetate $=$ $85: 15$ ) and by HPLC ( $n$-hexane/ethyl acetate $=95: 5$ ) to give 28 $\mathrm{mg}$ of $\mathbf{2 b}$ in $53 \%$ yield as a pale yellow amorphous solid. ${ }^{1} \mathrm{H}$ NMR (300 MHz, $\left.\mathrm{CDCl}_{3}, \mathrm{TMS}\right) \delta=0.98\left(\mathrm{~d}, J=7.1 \mathrm{~Hz}, 6 \mathrm{H}, \mathrm{CH}_{3}\right)$, 2.35 (s, 3H, $\mathrm{CH}_{3}$ ), 2.68 (sept, $\left.J=7.1 \mathrm{~Hz}, 1 \mathrm{H}, \mathrm{CH}\right), 6.80(\mathrm{~s}, 1 \mathrm{H}$, Aromatic H), 7.2-7.7 (m, 9H, Aromatic H). ${ }^{13} \mathrm{C}$ NMR $(75 \mathrm{MHz}$, $\left.\mathrm{CDCl}_{3}\right) \delta=14.0,19.7,29.2,104.8,111.6,119.2,119.8,122.8$, $124.3,125.5,126.0,126.3,126.7,129.5,130.9,142.1,149.5$, 154.3, 156.8. IR ( $\left.v, \mathrm{KBr}, \mathrm{cm}^{-1}\right): 422,486,561,596,646,688$, 750, 800, 837, 864, 904, 928, 991, 1074, 1136, 1198, 1278, 1309, 1340, 1456, 1493, 1579, 2852, 2877, 2937, 2978, 3039, 3066. HRMS (MALDI) $m / z=538.1030\left(\mathrm{M}^{+}\right)$. Calcd for $\mathrm{C}_{27} \mathrm{H}_{20} \mathrm{~F}_{6} \mathrm{O}_{3} \mathrm{~S}=$ 538.1032

\subsubsection{1-(2-Isopropyl-3-benzofuryl)-2-(2-isopropyl- 5-phenyl-1,1-dioxide-3-thienyl)perfluorocyclo- pentene $(3 \boldsymbol{b})$}

$m$ CPBA (62 $\mathrm{mg}, 0.36 \mathrm{mmol}$ ) was added to a stirred dichloromethane solution $(3.0 \mathrm{~mL})$ containing 3a $(55 \mathrm{mg}, 0.10$ mmol). The reaction mixture was stirred overnight in the dark at room temperature. The reaction mixture was extracted with dichloromethane. The organic phase was dried over $\mathrm{MgSO}_{4}$, filtered, and evaporated. The crude product was purified by column chromatography on silica gel ( $n$-hexane/ethyl acetate $=$ $85: 15$ ) and by HPLC ( $n$-hexane/ethyl acetate $=95: 5$ ) to give 31 $\mathrm{mg}$ of $\mathbf{3 b}$ in $53 \%$ yield as a pale yellow crystal. $\mathrm{mp} 111-112{ }^{\circ} \mathrm{C}$. ${ }^{1} \mathrm{H}$ NMR $\left(300 \mathrm{MHz}, \mathrm{CDCl}_{3}, \mathrm{TMS}\right) \delta=0.95(\mathrm{~d}, J=6.9 \mathrm{~Hz}, 6 \mathrm{H}$, $\left.\mathrm{CH}_{3}\right), 1.27\left(\mathrm{~d}, J=6.9 \mathrm{~Hz}, 6 \mathrm{H}, \mathrm{CH}_{3}\right), 2.6-2.9(\mathrm{~m}, 2 \mathrm{H}, \mathrm{CH}), 6.79(\mathrm{~s}$, 1H, Aromatic H), 7.3-7.7 (m, 9H, Aromatic H). ${ }^{13} \mathrm{C}$ NMR $(75$ $\left.\mathrm{MHz}, \mathrm{CDCl}_{3}\right) \delta=19.8,20.9,27.6,29.2,102.0,111.8,119.4$, $119.7,122.4,124.2,125.3,126.4,126.7,129.5,130.9,142.1$, 149.7, 154.4, 163.9. IR ( $\left.v, \mathrm{KBr}, \mathrm{cm}^{-1}\right): 420,488,559,596,648$, 688, 752, 802, 827, 870, 904, 937, 993, 1053, 1068, 1142, 1198, 1277, 1311, 1338, 1456, 1601, 2877, 2937, 2978, 3039, 3066. HRMS (MALDI) $m / z=566.1426\left(\mathrm{M}^{+}\right)$. Calcd for $\mathrm{C}_{29} \mathrm{H}_{24} \mathrm{~F}_{6} \mathrm{O}_{3} \mathrm{~S}=$ 566.1423 .

\section{Acknowledgments}

This work was partly supported by a Matching Planner Program (No. MP27115663071) from Japan Science and Technology Agency (JST) and a Grant-in-Aid for Scientific Research on Innovative Areas "Photosynergetics" (No. 26107013) from The Ministry of Education, Culture, Sports, Science and Technology (MEXT), Japan. The authors also thank Nippon Zeon Co., Ltd. for providing octafluorocyclopentene.

\section{References}

1. Crano, J. C.; Flood, T.; Knowles, D.; Kumar, A.; Van Gemert, B. Pure Appl. Chem. 1996, 68, 1395-1398.

2. Irie, M.; Matsuda, K. In Electron Transfer in Chemistry; Balzani, V. Ed.; Wiley-VCH, Weinheim, 2001; pp. 215-242.

3. Irie, M. In Molecular Switchings; Feringa, B. L. Ed.; Wiley-VCH, Weinheim, 2001; pp. 37-62.

4. Delaire, J. A.; Nakatani, K. Chem. Rev. 2000, 100, 1817-1846.

5. Bechinger, C.; Ferrere, S.; Zaban, A.; Sprague, J.; Gregg, B. A. Nature 1996, 383, 608-610. 
6. Kobatake, S.; Takami, S.; Muto, H.; Ishikawa, T.; Irie, M. Nature 2007, 446, 778-781.

7. Irie, M. Chem. Rev. 2000, 100, 1685-1716.

1

8. Irie, M.; Fukaminato, T.; Matsuda, K.; Kobatake, S. Chem. Rev. 2014,

114, 12174-12277.

9. Jeong, Y. C.; Han, J. P.; Kim, Y.; Kim, E.; Yang, S. I.; Ahn, K. H. Tetrahedron 2007, 63, 3173-3182.

10. Jeong, Y. C.; Yang, S. I.; Ahn, K. H.; Kim, E. Chem. Commun. 2005, 2503-2505.

11. Jeong, Y. C.; Yang, S. I.; Kim, E.; Ahn, K. H. Tetrahedron 2006, 62, 5855-5861.

12. Uno, K.; Niikura, H.; Morimoto, M.; Ishibashi, Y.; Miyasaka, H.; Irie, M. J. Am. Chem. Soc. 2011, 133, 13558-13564.

13. Sumi, T.; Kaburagi, T.; Morimoto, M.; Une, K.; Sotome, H.; Ito, S.; Miyasaka, H.; Irie, M. Org. Lett. 2015, 17, 4802-4805.

15. Shoji, H.; Kobatake, S. Chem. Commun. 2013, 49, 2362-2364.

16. Shoji, H.; Kitagawa, D.; Kobatake, S. New J. Chem. 2014, 38, $933-$ 941.
17. Chen, D. Z.; Wang, Z.; Zhang, H. H. J. Mol. Struct. (Theochem) 2008, $859,11-17$.

18. Kobatake, S.; Irie, M. Chem. Lett. 2003, 32, 1078-1079.

19. Morimitsu, K.; Shibata, K.; Kobatake, S.; Irie, M. Chem. Lett. 2002, 572-573.

20. Morimitsu, K.; Shibata, K.; Kobatake, S.; Irie, M. J. Org. Chem. 2002, 67, 4574-4578.

21. Kobatake, S.; Uchida, K.; Tsuchida, E.; Irie, M. Chem. Lett. 2000, 1340-1341.

22. Kitagawa, D.; Sasaki, K.; Kobatake, S. Bull. Chem. Soc. Jpn. 2011, 84, 141-147.

23. Shoji, H.; Kitagawa, D.; Kobatake, S. Res.Chem. Intermed. 2013, 39, 279-289.

24. Ortega, N.; Urban, S.; Beiring, B.; Glorius, F. Angew. Chem. Int. Ed. 2012, 51, 1710-1713.

25. Yamaguchi, T.; Irie, M. J. Org. Chem. 2005, 70, 10323-10328.

26. Ren, P.; Wang, R.; Pu, S.; Liu, G.; Fan, C. J. Phys. Org. Chem. 2014, $27,183-190$ 


\section{Graphical Abstract}

To create your abstract, type over the instructions in the template box below.

Fonts or abstract dimensions should not be changed or altered.

\section{Photochromic reaction behavior and thermal stability of thiophene-S,S-dioxidized diarylethenes having a benzofuryl group}

Koki Tanaka, Daichi Kitagawa, Seiya Kobatake*

Department of Applied Chemistry, Graduate School of Engineering, Osaka City University, 3-3-138 Sugimoto, Sumiyoshi-ku, Osaka 558-8585, Japan

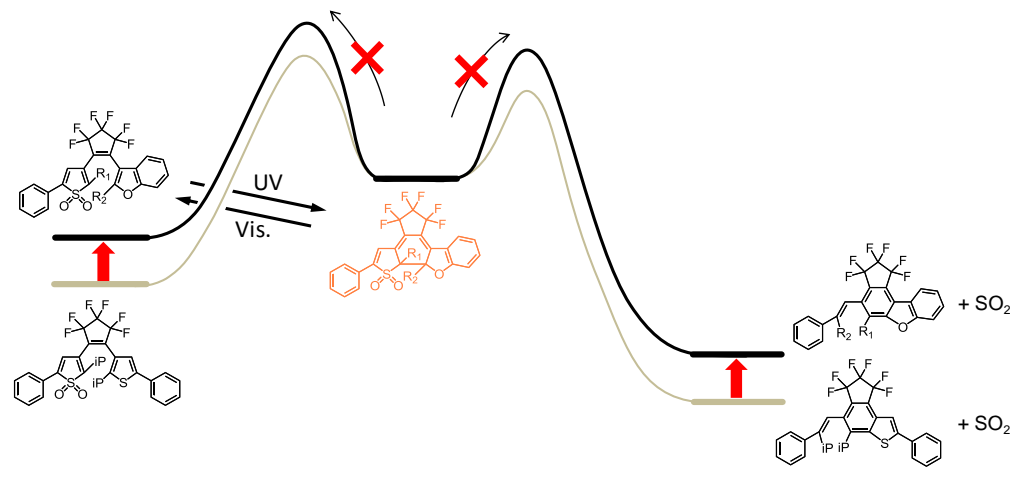

